\title{
THE TERRIBLE WORD
}

\author{
Shane Carreon \\ University of the Philippines Cebu \\ clcarreon1@up.edu.ph
}

\section{About the Author}

Shane Carreon is author of the poetry collections, travelbook (2013) and Then, Beast (forthcoming) and a recipient of the Carlos Palanca Memorial Award for Literature, the Nick Joaquin Literary Award, and SUNY Binghamton 2016 AWP Intro Journal Awards for Poetry. Her works recently appear in Veils, Halos and Shackles: International Poetry on the Oppression and Empowerment of Women and is forthcoming in Callisto: A Queer Fiction Journal. She is a faculty at UP Cebu and is currently on Fulbright Scholarship at SUNY Binghamton 


\section{THE GOAT}

after L. Gutierez's "Childhood Pain"

Father slaughtered a goat

on my ninth birthday to remember

losing mother.

The sun was bright. The sound of chickens

clawing the ground for worms,

my sister cutting leeks,

and the goat, no bigger than I was,

calling for help. I was afraid

of blood and sorry for its fate...so I ran

to the river where my friends were

laughing and digging mud, burying

beetles. Did the rushing

river drown the sound of my name?

My sister appeared, gasping.

Father, she said,

is looking for you. I knew what it meant.

The bamboo in his hand.

Who was it screaming

so hard it tore the air? What was it

that whipped and whipped.

I heard my sister's cries, somewhere

beyond my ears, mother's as well.

The goat's, too, from the gut

like mine.

Father was very strong. He dragged me by the hair.

Who screams 
for my body?

I felt a body

pushed down the stairs. I felt a body

on the kitchen floor. Whose is this

limp and dull I pulled to the wide cornfield?

The corn were already grown, taller than I was.

I cried, until it was dark

and I was afraid to be alone.

So I returned home. 


\section{FATHER'S BIRTHDAY}

My father's birthday yesterday, I remembered but chose

Not to say anything. The backstory is long,

An unlit hallway echoing of stroking hands

In a partially closed room not far

From where most people stay to admire the garden

We keep, among others. Stoicism is plenty,

So is civility. The surfaces clear, spotless from

Hostility as a glass table. Mother expected me to call

Because I was supposed to

Be grateful after Steven, love of my life, sat in the patio;

Father on the wicker chair, eyes half closed;

Mother, pruning.

She must be upset, not replying to the message I left

Today like an afterthought, pretending forgetfulness.

Of course, she knows and has chosen

Not to remember. My poor brave mother

Whose fecund dreams must have been as bright as she

Was before bearing an only child, son so similar

To the father who, in darkness, bears his fruit. 


\section{SALVACION STREET}

The days before I was twelve,

Salvacion was the asphalt road

extending past

the neighborhood homes,

the generations-long Three Sisters

Store, Chapel of Fatima,

the vulcanizing shop

and beyond,

the tamarind tree with its old

weathered rope hanging loose.

And farther still,

through mangroves and fields

of coastal rocks

at the end of the island.

Sea.

The days before I was twelve,

tambis flowers fell

whenever the wind blew

outside my bedroom windows.

And while the rest of the family

watched on afternoon TV

the striking man kissing

the dainty woman,

I climbed out to escape siesta.

Soon, I would know the terrible

word between love.

But at that moment,

I held onto the handlebars

And pedalled my way to shore. 